Chapter 1

A Capital In the Margins: Concepts for a Budapest Universal Exhibition Between 1867 and 1917

\title{
Miklós Székely
}

In the region of Central Europe, universal and international exhibitions shared many features with their western precedents. At the same time, however, they adopted independent agendas, related to the specific political circumstances in which they were organised. Hungary, as part of the Dual Monarchy of AustriaHungary, provides an especially pertinent example of such autonomous transformation of the exhibition medium, which was used to proclaim the Hungarian sovereignty, modernity and national identity.

In general, universal exhibitions were addressed to international audiences and in most cases were organized in national capitals with ever increasing number of exhibitors. The evolution of universal exhibition can be traced back to national industrial exhibitions at the end of the eighteenth century, which displayed diversity of goods and artefacts created nationwide. In the course of the nineteenth century, small trade fairs and industrial exhibitions around Europe increasingly opened up to international exhibitors and audiences. The first industrial exhibitions adopted the name 'general exhibition' in the last quarter of the nineteenth century. In the geographical context that will be the subject of analysis here, examples of such events include Országos Általános Kiállítás (The General National Exposition) in 1885 in Budapest or the Expoziţia Generală Română (Romanian General Exposition) in 1906 in Bucharest. They focused on a wide 
range of exhibits, but especially those produced locally. Universality, seen in the character of the exhibited goods, objects and inventions, remained the leitmotif for great fairs that put on display the latest and diverse material culture of the everyday life, important technical inventions and industrial products which were collected from international exhibitors. As the century "progressed" the need for exhibitions specializing in fewer products and inventions increased although these events retained their international character by inviting foreign participants. The first International Art Exhibition in Venice in 1895 (today's Venice Biennale) originally started as an international exhibition specialized in fine arts while the International Health Exhibition in 1884 in London attracted international exhibitors of a new kind of specialization of the modern casual life.

Between 1867 and 1917, a number of attempts were made in Hungary to organize an international exhibition. The history of proposals for a Budapest Universal Exhibition therefore reveals the political and constitutional contradictions that the modern Hungarian state had to face as a result of the Austro-Hungarian Compromise of 1867. This contribution examines the cultural and political circumstances of these ambitious projects and the social and cultural background of the main initiators in order to understand the variety of influences that shaped exhibitions and their proposals. The analysis contributes to the understanding of the vulnerable position of the Hungarian cultural policy at the turn of the century. The stages of the formation of a modern nation were reflected in its participation at international exhibitions and in the will of hosting such a show in Budapest. Hungary shared similar intentions of nation building with many other countries in Central Europe that lacked full national sovereignty, which also 
hosted exhibitions displaying the best that the respective nations had achieved. The example of Hungary's attempts for a universal exhibition shows a determination of a nation in the making in constructing its own image using the modern and popular medium of exhibition while negotiating its internal politics and ethnic minorities.

\section{Identity of the Hungarian State after 1867}

The European universal exhibitions of the 1850s and 1860s coincided with significant changes in Hungary's political status and the construction of its political and cultural identity. The Kingdom of Hungary was a part of the Habsburg Empire until 1867 when the compromise with Austria converted the Empire into the Austro-Hungarian Dual Monarchy. ${ }^{1}$ The previously gradual modernization of the Hungarian economy and culture accelerated when Hungary became one of the two political and administrative entities of the Austro-Hungarian Monarchy. It was only within the legal and internationally recognized framework of the Dual Monarchy that Hungary gained this relative degree of self-government. Apart from a few joint ministries of finance, foreign affairs, and war, Austria and Hungary were led by separate governments under the same ruler: the Emperor Franz Joseph I, based in Vienna who was also the Apostolic King Franz Joseph, whose official seat was in Budapest. From the Hungarian historical and juridical perspective, Franz Joseph represented the continuity with the medieval kings of Hungary. ${ }^{2}$

The question of 'being Hungarian' did not in the least manifest aspirations for political independence as the Hungarian parliamentary parties, the Liberal and the Independence Party alike, unanimously accepted the rule of the House of 
Habsburg. After 1867, the modern nation building process was based on the Hungarian constitution, which in the view of national politicians dated to 1222 . It was the legal foundation for the modernization of the country, based on its ancient political, economic and cultural heritage. For contemporary Hungarians, the restoration of historic Hungary in politics, economics and culture was a constitutionally based process of reconstruction.

Between the 1867 Compromise and the First World War, the terms sovereign and Hungarian remained the central concepts of nation-building, reinforced by the conscious construction of the country's image abroad. Using the constitutional lines, the political elite, mostly of aristocratic origin, was continuously willing to construct and show the sovereign and Hungarian economy and culture - thus representing the country abroad beyond the administrative capacities ensured by the limits of the Compromise, which entailed a reinterpretation of some historical facts, as will be mentioned shortly.

Such image making that Hungary engaged in can also be discerned in its politics of participation in universal exhibitions. Because of the Viennese political absolutism, the Hungarian presence was imbedded within the section of the Austrian Empire in the first three universal exhibitions of 1851, 1855 and 1862. At the London (1851) and Paris (1855) universal exhibition, Hungarian exhibitors participated in a minor and fragmented way and objects of Hungarian origin were displayed among Austrian exhibitors' goods and pieces. The Hungarian economy was presented as being on the same level with the Austrian hereditary provinces and primarily as a source of agricultural products and raw minerals. Evidence of an improved political situation were the Hungarian sections at the 1862 Great London 
Exposition organized by the council of governor-general in Buda, which was, nevertheless, still run under the strong authority of the Viennese court. In the economic sections, the country was primarily represented by its natural resources. However, a collection of applied arts objects and a small fine art collection were also exhibited and included a few works by contemporary Hungarian painters: historical scenes and genre paintings by Gyula Benczúr, Mór Than, Károly Lotz and Bertalan Székely, the pupils of Karl von Piloty and Georg Ferdinand Waldmüller, who represented the latest artistic influences of the Munich Academy. ${ }^{3}$

The position of Hungary changed fundamentally after 1867. In culture and in internal politics, it became fully autonomous and this resulted in a sea change in its representation at fairs abroad. Beginning with the 1867 Paris exposition universelle, Hungarian thematic exhibition groups were organized by national commissars under the auspices of the Hungarian government. Thus, in the year of the political compromise with Austria, Hungary also made an independent debut on the international stage. An important sign of the new Hungarian approach to organization was the publication of a catalogue of the national exhibits in French, for the first time edited by a Hungarian exhibition committee and published in Paris. $^{4}$

At the 1867 exposition universelle architecture was employed to represent national politics and thus the image of the sovereign and Hungarian state. The economic development of the country was articulated not only in the purely economic sections of industry, mining and agriculture but also in the industrial and applied arts sections. This division set a precedent and reappeared in Hungarian national exhibitions before the turn of the century. 
The displays of Hungarian political, economic and cultural 'sovereignty' required visionary perspectives. This motivated the use historic reference as a political tool: the revival of historic styles in Hungary has its roots in the Hungarian representational ideas beginning in the 1860s. An exhibition of historical forms outside the national borders was an echo of much stronger internal political connotation. One of the first manifestations of such an approach is contained in the memoirs of the Transylvania-born Countess Emma De Gerandó Teleki. In her description of the Hungarian section at the Paris Exposition Universelle of 1867, Countess De Gerandó paid special attention to the self-image of modern Hungary. ${ }^{5}$ She also presented a plan for upcoming exhibitions, which included exhibition rooms entirely carved from salt from the Transylvanian town of Marosakna (today Ocna Mures) which would represent the mineral richness of Transylvania, a region she considered purely Hungarian. The reconstruction of the Hunyadi family's famous castle in Vajdahunyad as an architectural reference to the aristocratic Hunyadi family, linked with the fifteenth century battles against the Turks and the introduction of quattrocento to Hungary, was another example of her attempt to construct a 'Hungarian' identity at future exhibitions. ${ }^{6}$

De Gerandó's vision complied with a trend that was popular at exhibitions in Europe and elsewhere at the time and which stressed the uniqueness of pavilions of individual nations. In the context of a universal exhibition, the architecture of national pavilions underwent important developments in the late nineteenth century; serving the representational needs of an increasingly secularized bourgeois society, the preservation of national memory and the entertainment of the masses. Nationally appropriated, the pavilion soon became 
the medium par excellence of national self-representation in universal exhibitions. ${ }^{7}$ However, at the 1867 exposition universelle, which the Countess visited, a new type of exhibition pavilions appeared. Small-scale pavilions, showcasing gastronomy or small entrepreneurs, appeared here for the first time in a considerable number and included a Hungarian display too.

The Hungarian wayside inn (csárda) was the only edifice aiming at representing Hungarian national characteristics here. Apart from serving as a political representation, proclaiming Hungarian sovereignty, it also promoted national economic interests: wine production and export were highly significant to the national economy of the 1860s and 1870s. The csárda building also reinforced a romantic perception of Hungary through the image of the Great Hungarian Plain (Puszta) with its ethnically diverse inhabitants wearing 'exotic' clothing. ${ }^{8}$ The distinctive csárda building referred to the only internationally known notion of the Puszta, as the Great Hungarian Plane was one of the most widely acknowledged topoi of Hungary in the nineteenth century. On the other hand, the rural character of this display highlighted the weak industrial position of Hungary to international audiences.

Only six years later, at the 1873 universal exhibition in Vienna, organized not by the entire Monarchy but by Austria alone, Hungary was invited as a participant. ${ }^{9}$ Taking advantage of this, Hungary appeared as a sovereign country with extensive and elaborate exhibition material. The forestry pavilion, for instance, served the interests of the state-owned forestry which provided significant state profit. As such, it became the first Hungarian pavilion to really meet its economic and marketing potential. Its design followed the traditional 
wooden architecture of the Greek Orthodox Church from the eastern Máramaros region which had mainly non-Hungarian inhabitants, especially the Ukrainian speaking Ruthenians and Romanian speaking Romanians. The emphasis on the Puszta romance prevailed in the 1870 s too, in the form of a country house from the Great Plain which served as a wine bar.

As the references to the ethnically mixed origin of the Hungarian pavilion in Vienna indicate, the new national administration faced the challenge of a great linguistic, ethnic and religious diversity of Hungary after the Compromise. ${ }^{10}$ During this period, the interest in ethnographic issues was as much political as it was scientific. The material objects and fleeting traditions that ethnographers documented served as fundaments on which the nation could be built.11 Ethnography played a crucial role in the multi-ethnic politics of both sides of the Dual Monarchy and this was manifested in the insertion of most ethnic groups into national representations at the Vienna fair. Here, a range of objects at the ethnographic village represented ethnicities from the territories of the empire through their dwellings. The Hungarian committee also displayed Hungary as a multi-ethnic region, with a series of peasant houses representing the Germans, Hungarians, Szeklers, Rumanians and Croatians. Their cultural and political importance influenced the selection: the Germans, Szeklers and Romanians represented the centuries-old ethnic diversity of Transylvania, while the almost nine hundred year long political union of Croatia with Hungary was made evident by the inclusion of a Croatian peasant house. ${ }^{12}$

After this relatively extensive Hungarian involvement in Vienna in 1873, Hungarian presence decreased significantly at the 1878 Paris Exposition 
Universelle. Here, under the auspices of a Monarchic representation, all Austrian and non-Austrian exhibits were put together on common exhibition grounds. Serving as an important diplomatic act right after the Franco-Prussian war and the failure of the Paris Commune in 1871, this Monarchic representation buttressed the supranational and peaceful aspects the Dual Monarchy wished to assert. The unified representation of Austria-Hungary was also a part of a larger royalist representation in the republican France: the German absence in Paris made the presence of the Dual Monarchy and Russia even more significant for the French diplomacy. In this joint exhibition the high quality industrial products from Bohemia and Austria indirectly highlighted the weakness of the Hungarian economy. As a consequence of the weak national representation in the economic sections the Hungarian government decided to abstain from further international exhibitions until the economic conditions attained European standards.

\section{Plans for the Budapest Universal Exhibition of 1874}

The idea to hold a universal exhibition in Budapest was encouraged by members of the nobility, industrial entrepreneurs and some members of the bourgeoisie and soon became popular among citizens of different social standing. One of first grand plans for a universal exhibition in Hungary was conceived by a talented individual and a patriot who remained more of an outsider and whose ideas did not come to fruition. The former army captain Szilárd Blána (1826 - ?), a political refugee who left Hungary after the 1848-1849 War of Independence, visited the 1851 Great Exhibition in London and later, as a passionate patriot, took part in the preparatory works of the Hungarian section for the 1867 exposition 
universelle in Paris. It was his personal experience with international exhibitions that prompted Blána to publish his work promoting the idea of a permanent exhibition grounds in Budapest. ${ }^{13}$

In Blána's eyes, the foremost aim of a universal exhibition as envisaged by Prince Albert - a representation of the material and spiritual development of Mankind with the aim of a continuous comparison - had not been entirely fulfilled in the five previous large events (London 1851, Paris 1855, London 1862, Paris 1867, Vienna 1873). Blána's patriotism and his positivistic approach had a crucial impact on his concept. Combined with his idealistic and nationalistic ideas, it differed very much from the established dynamic economic concept of the universal exhibitions based on regularity and shifting locations among economic centres.

The permanent exhibition space in Budapest, Blána envisioned, would mostly serve Hungarian national economic development through the presentation of the latest universal trends in economy, industry and culture. Through the concentration of goods and products in one place over the course of a limited time, universal exhibitions answered the need of a modern society for universal publicity to learn about the latest achievements of urban modernity. ${ }^{14}$ Exhibits displayed in the permanent venue, which would be constantly changing as Blána proposed, would ensure a never-ending influx of foreign visitors.

The exhibition area would include displays of six continents of the world classified according to their level of development, as Blána saw it: Europe, America, Asia, Africa, Australia and Oceania. The size of the exhibition spaces would not relate to the geographical dimensions of the continent, but would be proportional 
to the 'intellectual and cultural level of its inhabitants', Blána suggested. ${ }^{15}$ The giant circular walled areas would present each of the nation's vegetation and mineral samples and the best artistic and industrial products which would be constantly replaced by more recent inventions and innovations. The purpose-built permanent 'temple of modern life' was conceived more as a permanent place of display rather than a temporary exhibition - in Blána's proposal it would become an immense library of progress. ${ }^{16}$

In the last decades of the nineteenth century, universal exhibitions were often linked to the idea of memory and commemoration. The first such occasion was the 1876 Philadelphia World Exhibition, organized to commemorate the centennial of the signing of the Declaration of Independence. The conception of this fair was already made public by the time of the 1873 Vienna exhibition and most probably influenced Blána as well. ${ }^{17}$ Due to the lack of original sources, though, a direct link cannot be established between the first commemorative type of a universal exhibition and Blána's ideas. It is, however, quite plausible that Blána believed the best moment for the inauguration of the Budapest exhibition space should correlate with the celebration of Hungary's Millennium because he was captivated by the idea of the exhibition at the core of the commemoration act.

Once the occasion, the commemoration of the Millennium, was agreed upon, it became clear that the exact date of this important event was uncertain not only for Blána but for contemporary historians as well. The arrival of the Magyars, referred to as the Hungarian conquest, happened at the end of the ninth century. Determining one precise and historically justifiable moment for this crucial event had been the subject of intense speculation in historiography and, due to the tense 
political conditions in Hungary, in politics. The title of Blána's proposition clearly refers to its aim: the celebration of the 'thousands of years of existence of the Hungarian kingdom in the year 1883'. ${ }^{18}$

Blána's vision of the exhibition's organization, financial matters and the national contributions was undeniably original and ambitious. He wanted to divide the construction site for each nation based on its population and cultural development and shift the construction fees to the national governments. Further, his plan contained a waterpark which included an exhibition field with lakes, fountains, canals and its own transportation service. He also stipulated an obligation for all nations to send a copy of their best industrial products and artworks. Apart from the temporary exhibition of the latest products, he considered the educational and museological aspects of the inventions and proposed to receive two copies of all new technical inventions so that they could be exhibited and published in the multilingual exhibition journal. While one artefact would be exhibited, the other would be displayed in a museum and placed in an international patent office to be set up in Budapest.

Blána also proposed that pavilions and national buildings should be erected in native materials and techniques by national professionals and that locals be sent to the exhibition to represent the diversity of national costumes and popular traditions. They would be in charge of the construction work, setting up the exhibition, hosting visitors, while they would be following (and displaying) their own local traditions. In brief, he imagined the foundation of national 'colonies' within the exhibition grounds. As there is only limited documentary evidence, the author's motivations for such colonial displays in the context of landlocked 
Hungary remain unclear. However, after several years abroad and his engagements in previous international exhibitions, Blána's vision must have been largely influenced by the colonialist approach to the non-western world he encountered here. His perception of an international exhibition, based on his travels and services in London and Paris, were therefore different from those of other Hungarian politicians and compatriots in charge of organising domestic exhibitions, all of whom were subjects of the Dual Monarchy, a non-colonizer European empire. ${ }^{19}$

Blána's idealistic and utopian plan was, however, unattainable partly due to the economic and financial limitations of Hungary and partly because of the unfeasibility of the exhibition's permanent character. It was, still, an important proof that the idea of an exhibition as a generator of modernization penetrated the entire Hungarian society. If implemented, the plan would have transformed Budapest into the spiritual and economic capital of Mankind, in which Blána believed. Its new role, according to Blána, would be to diffuse the achievements of the Enlightenment such as secularization, fraternity, progress and culture. Obviously such a highly ambitious aspiration was impossible to realize, not only for Hungary but for any other nation at that time. In Hungary, Blána's visionary patriotism and utopian technocracy were contrary to the nobility's collective memory of Hungarian medieval greatness. Although Blána's paper echoed a shared vision of his contemporaries, he was but a visionary patriot with no social capital or recognition - and this might explain the fact why Blána's exhibition plan remained unnoticed in future exhibition planning related to Hungary's efforts. ${ }^{20}$ 


\section{Commemorating the foundation of Hungary in 1896}

The problem of establishing an exact conquest date to be commemorated by the Millennium festivities, that Blána had faced, was passed to the Hungarian Academy of Sciences by the government in 1882. A committee of scholars determined a twelve-year long period between 888 and 900 during which the event likely happened. For practical reasons the date of the festivities was set to 1894 but for organizational purposes it was later postponed to 1896 . Not only the date but also the content of the Millennium was a point of discussion. This included talks about new monuments, a new parliament building, a National Pantheon in Budapest, festivities and commemorative acts. ${ }^{21}$

A key figure in the Millennium preparations was Count Jenő Zichy (18371906). In June 1890 he came up with a draft programme for the Millennium celebrations, which became the first and complete overview of the festivities; its printed version served as the basic for the future organization. Zichy, unlike Blána, was a prominent figure of the time, a promoter of industrial education, President of the National Industry Society, a generous patron of the fine arts and a passionate amateur of archaeology, national prehistory and historic monuments but his most important activities were linked with domestic exhibitions. Starting in the 1840s, Zichy had organized a series of national industrial exhibitions, with the first held in Székesfehérvár, central Hungary, in 1872 and one in Budapest seven years later. The latter one, the National General Exhibition of 1885 although smaller in scale was similar in content to the planned Millennium Exhibition as it focused on industrial and agricultural achievements of Hungary. 
The Millennium soon turned into an event of great national enthusiasm. Intellectuals, politicians, priests, noblemen and even ordinary citizens promoted their ideas of how to commemorate this event. Zichy's proposal to organize a universal exhibition on the occasion of the Millennium was officially submitted to parliament by the Art Amateurs' Society in June $1891 .{ }^{22}$ Combining the national, international and universal aspects, Zichy considered the arrival of the Magyars as an important event from a global perspective, so a universal exhibition would serve as an international frame for the commemorative festivities of the national jubilee. Zichy attributed a major role to the exhibition for a simple practical reason: opened for a period of six months, it would create a continuity among the various commemorative events, which included the joint jubilee session of the upper and lower chambers of the Parliament and the inauguration of a sculpture on Gellért hill in Budapest at the occasion of the closing of the commemorative year. Zichy planned the exhibition to be listed as the fourth item on a long list of festivities, which comprised seven components altogether: various national festivals, religious celebrations, a theatrical procession representing 'the ten centuries of Hungarian history', the exhibition, theatre and music performances, sport games and many other popular events.

The Exhibition was a proclamation of Hungary's historicity as well as modernity. ${ }^{23}$ The contemporary aspect of the Exhibition was contained in the representation of the latest economic and cultural achievements of Hungary in the Main Contemporary Group, which consisted of, among others, industrial, ethnographic and art sections. The retrospective part of the Main Historical Group, housed in a romantic pavilion composed of replicas of 22 different historic 
buildings, focused on the historical development and culture going back to the coronation of St. Stephen King of Hungary in 1000. The interiors of the Main Historic Group displayed reconstructions of significant historic venues in the Hungarian history that were an example of a late inspiration in the museological concept of the French archaeologists Alexandre Lenoir and Alexandre du Sommerard in their creations of a lively atmosphere in the spirit of a Habsburg oriented historiography. ${ }^{24}$

Starting in the 1870s, the public discourse had long been focused on the historical and political aspects of the Millennium, which included debates on the nation's origin but also the circumstances, the heroes and the possible timeframe of the conquest. This coincided with the spread of exhibitions - both of industrial, special and general profile - in Hungary and the rise in their popularity. The combination of a notable historical event and a large, national exhibition therefore proved successful.

\section{Constructing a modern nation in art and architecture}

The commemoration of Hungary's Millennium was not, however, limited to domestic displays in Budapest, but extended to exhibitions abroad. Hungary officially joined the 1900 exposition universelle in Paris as a participant and invested more financial, economic and intellectual effort into its national presentation than ever before. The Hungarian installations of various thematic groups in the great exhibition galleries employed in part the architectural style of Ödön Lechner (1845-1914) who had tried to develop a Hungarian 'national' language in architecture that applied folk patterns and motifs to facades and who 
was inspired by Bekleidungstheorie, the theory of dressing, of the German architect and architectural theoretician Gottfried Semper. ${ }^{25}$ The Hungarian installations in Paris were designed by two Lechner's students, Zoltán Bálint and Lajos Jámbor. The floral decoration of the immense galleries' interiors, inspired by peasant art, was conceived to highlight the visual distinctiveness of the Hungarian culture. Beside the economic and cultural sovereignty exhibited in the galleries of the Hungarian historical pavilion in the Rue des Nations, the country's officially appropriated historical narrative was emphasized through a mixture of historic and vernacular architectural elements. Its decoration, the first example of the use of vernacular motives on ephemeral constructions, opened the way to the use of vernacular motifs and premodern tendencies in Hungarian pavilions during the forthcoming decades.

In contrast to the csárda-style Hungarian pavilions, which emphasized an idyllic puszta-image of the country at the international exhibitions in the 1860s and 1870s, mentioned above, after about 1905 Hungarian self-definition radically changed. The Liberal Party which gained a majority in the Parliament for thirty years at eight consecutive elections lost its seats. The years 1905-1906 were a period of significant internal political tensions in Hungary, which affected presentation of Hungary at international exhibitions. The new image took vernacular arts and architecture as a source for the new culture of modernized Hungary. ${ }^{26}$ As in many other parts of the Habsburg Empire, many young artists, architects and passionate amateurs understood peasant traditions as preserving national roots and the memories of the nation's past. As remnants of the mythic past, they interpreted peasant culture as the foundation of reinvented national 
myths and tales, and, what is more, important from the political point of view, encouraged attempts to revive national vocabulary in art and architecture. ${ }^{27}$

At the turn of the century, patterns and motifs inspired by peasant art outsourced especially from the Hungarian speaking region of Kalotaszeg in Transylvania, the Great Hungarian Plain and the Matyó land - decorated architectural elements as a common characteristic in the lands of Austria Hungary and beyond. Architectural structures and peasant art objects were not considered as autonomous exhibits anymore. They were reinterpreted and served as the basis for new structures and ornaments. In political terms, this new Hungarian art and architecture reflected the new concept of Hungary as a modernized, large and powerful historic state. This ambitious new image was based on the memory of the political and economic power of medieval Hungary and combined with the new economic and cultural achievements the country enjoyed since the AustroHungarian Compromise. The reinvention and popularization of traditions seemed historically, culturally and judicially justified, a natural consequence of the country's political and economic modernization.

The use of art and architecture for national representation became a major element of the official cultural politics after the 1896 Millennium exhibition and during the subsequent two decades. Part of the new and nationalistic paradigm of the national representation Hungarian pavilions reflected the image of a culturally sovereign country. Still, there was no attempt to proclaim political independence, rather, national life was envisioned within the framework of the Habsburg Monarchy and the political concept of being Hungarian and sovereign therefore did not exclude the acceptance of the 1867 Compromise. 
The stylistic diversity of the turn of the century international art and architecture tendencies had not only different aesthetic but also a different cultural and political background in each country. At the Paris Universal Exhibition in 1900 Hungary seemed to find its own voice in the mixture of vernacular traditions and pre-modern tendencies. ${ }^{28}$ By the turn of the century the notion of culture had changed, and reflected a bounded nature of the Hungarian nation. All objects related to the inherited past were conceived to ensure the nation's historical grounding while the ethnological interest began to focus on ethnic Hungarians as heirs of an ancient heritage. ${ }^{29}$ This was definitively not a new phenomenon; the nationalistic approach of the Hungarian political elite at this time had its origins already at the time of the Compromise of 1867 and in Countess De Gerandós proposal for Hungarian exhibitions at the 1867 exhibition. Moreover, such attitude was not unique and had close parallels in the Czech, German, Finnish or Polish approach which at this time used politically motivated references to ethnicity and the most ancient rural roots to construct their respective national identities. ${ }^{30}$

At the turn of the century, Hungarian folk art tradition was used following a new paradigm: it was promoted as features of modern national art and architecture and this became an important factor in pavilion architecture and decorative art objects. ${ }^{31}$ Such use had not only a political but also an important economic motive: products decorated in the modern national style enhanced the country's international recognition and were successful on the market as part of a more general trend of the vernacular revival in Central Europe. The promotion of vernacular modernism - through the interpretation of folk traditions - was based on a more organic way of conceiving national architecture and art. ${ }^{32}$ Between 1906 
and 1911 vernacular modernism was an appropriated representational tool for the state; its promotion in the medium of exhibitions was strengthened by professionalization of the exhibition industry. ${ }^{33}$

In the 1910s, Hungarian art and architecture, which appeared in the international context of exhibitions, included also the use of ornaments borrowed from objects that dated back to the conquest period and the arrival of the Hungarians. In the spirit of the romantic nineteenth century idea of peasantry, such objects were seen as proof of a historical national art vocabulary - they were tangible and much more concrete than one could have imagined some decades ago. At the 1911 Turin Esposizione internazionale dell' industria e del lavoro (The International Exhibition of Industry and Labour), for instance, the display of Hungarian works and goods appeared to form a unity with the exhibition pavilion; the interior of the exhibition space was no longer merely a stylistically adequate frame, but became itself an exhibited object. Wood as an important material of pavilion architecture beside plaster was used as a bearing structure as well as a visible, ornamented structural element, inspired by vernacular Transylvanian architecture, and one that proclaimed the connection between material and the structural solution. ${ }^{34}$

The Hungarian pavilion in Turin was designed by Dénes Györgyi, Emil Tőry, Móric Pogány, whose intention was to combine vernacular Hungarian architecture with modernism. The mostly wooden edifice combined the architectural approach of Károly Kós (1883-1977), a Transylvania-born architect of German origin and of Hungarian identity, with the architectonic language of the Young Ones, a group of young architects who began their careers around 1907 after graduating from the 
Budapest University of Technology. Their design was based on the TransylvanianHungarian vernacular traditions and combined late Secessionist, pre-modern architectural elements with heavy figural monumentality reminiscent of Franz Metzner's Battle of the Nations Monument in Leipzig or the semi-cupola designed by Béla Lajta in the Charity Home of the Chevra Kadisha in Budapest. The exhibition displayed works of several well-known Hungarian designers, including Géza Maróti, Ede Telcs, Miklós Ligeti, Miksa Róth, gaining an outstanding importance from the perspective of domestic public opinion and foreign markets. ${ }^{35}$ The interior of the pavilion and the installation were an exemplary summary of the official governmental position and of how the head of the art department of the Ministry of Religion and Education, Elek Koronghi Lippich (1862-1924), saw Hungarian industrial art based on vernacular traditions and, at the same time, preserving its alleged oriental (Asiatic) characteristics. ${ }^{36}$ Art and architecture, with strong historical references, gained political and economic significance when displayed in domestic and international exhibitions.

\section{Commemorating the coronation of Franz Joseph}

As pointed out before, most of the Hungarian sections at the international exhibitions between 1900 and 1911 attempted to represent Hungary as a modern nation. The pavilions in Turin (1902 and 1911), Saint Louis (1904), Milan (1906), Bucharest (1906) Rome (1911) and Dresden (1911) were conceived as 'true mirrors' of the modernized economy and cultural policy of Hungary for a mostly foreign audience. Even if Hungarian self-representation was defined by strong historical awareness of the political and financial elite devoted to national 
conventions, their main aim was to make the economy prosper and to refine and modernize culture generally.

In the pre-WWI period, the global exhibition enterprise underwent significant changes as the national organizations, commerce museums and exhibition centres ensured the professionalization of universal exhibition organization worldwide. These changes also influenced the last project for a universal exhibition in Budapest which closes an important chapter in the Hungarian exhibitions history. The grand plans were devised by Leo Lánczy (1852-1921), an assimilated Jewish member of the Upper House, president of the Budapest Chamber of Commerce and Industry and a liberal patriotic plutocrat. Lánczy's proposal was again linked to commemoration, this time to the fiftieth anniversary of Franz Joseph's coronation as King of Hungary and of the Compromise in 1867. Since this double political act was seen as the reestablishment of the (nearly) sovereign State of the Lands of the Crown of St. Stephen, Franz Joseph appeared to be the 'second founder of the country', establishing a link to Saint Stephen's crowning as the first Christian king of Hungary.

Lánczy submitted his proposal to Károly Hieronymi, the minister of trade and commerce in February 1911, only a couple of months before the opening of the Turin exhibition. ${ }^{37}$ He referred to Zichy's 1891 proposition which asked for the Millennium celebrations to be turned into a universal exhibition. Lánczy, a wealthy banker and a promoter of the latest industrial and financial innovations in Hungary and a patron of the fine arts had much in common with Count Zichy. The national economic, industrial, and agricultural factors, which had contributed to the 
country's fast growth after 1867, formed an important part of his concept. He argued that the Millennium Exhibition was as an example of how a universal exhibition could put the country's economy and cultural life on an international map. ${ }^{38}$ In his view, participation of Hungary at exhibitions abroad brought some 'beautiful results' for the economy but, as he stated, none of these shows ensured a conveniently high percentage in the exhibition section to represent the latest achievements of the economic and cultural modernization of Hungary after 1867.39 So, as Lánczy had argued, the Budapest Universal Exhibition would fulfil the long existing aspirations for the recognition of the economic, technological and cultural modernization Hungary by the international audience. Due to the restrictions on the exhibition area of the invited counties as compared to the host, the 'abundance, diversity and excellent qualities' of the Hungarian products could not be presented in full. ${ }^{40}$ Lánczy claimed that invited countries were altogether given the same area which was equal to the size of the space occupied by the host country, as was often the practice. The proposed Budapest Universal Exhibition of 1917 would therefore provide opportunities for a larger scale Hungarian products, the full spectrum of presentation and comparison, since, as he stated:

Here we see which of our products are competitive and where and in what field we are lagging behind. [...] It is clear that the Budapest Universal Exhibition would promote all aspects of our economic and cultural life and ensure new opportunities and new perspectives for our development. ${ }^{41}$

Lánczy also highlighted the direct and indirect advantages, which he saw in tourism and innovation and investment which Budapest with nearly one million inhabitants could benefit from. He also considered all direct political gains of such an event which would be the worthiest celebration of the jubilee in the year of 
1917, a celebration that would serve as an occasion to invite foreign states and civilized nations and to present the country's achievements of the previous halfcentury. ${ }^{42}$

Lánczy maintained that at universal exhibitions abroad Hungarian economic and cultural policies were identified with sovereign (economically and culturally separated from Austria) and Hungarian (historically relying on its own constitution). Lánczy intended not only to raise the international reputation of Hungary but, more importantly, to construct an image of the country as a selfsufficient political entity. This was still a dream at the time, for in foreign policy and in military issues Hungary was not sovereign and decisions were made by Emperor Franz Joseph. Still, the Hungarian government made several efforts in the prewar period to increase the visibility of Hungary as a sovereign entity and not a mere province of Austria. 'It is a fact that even those foreigners who sympathize with us, in many cases, consider us from a romantic perspective and appreciate us from an ethnographically interesting perspective'. ${ }^{43}$ As a passionate freemason, Lánczy ultimately believed that the bloody rivalry between nations would be moved to the peaceful terrain of international trade and commerce of which the universal exhibition would be the utmost tool. ${ }^{44}$

The official position of the Hungarians on Lánczy' proposal is unknown. After six decades of Hungarian participation at foreign universal exhibitions, his arguments were probably familiar to most Hungarian politicians, entrepreneurs and economists. Despite the fact that no parliamentary or ministerial records can be found in any reference to the discussion of the draft, Leo Lánczy printed and 
edited his proposal for the Budapest Universal Exhibition, which, ultimately, was the last attempt of this kind.

Generally, a universal exhibition requires five to ten years to get organized. Even though Lánczy's ideas had been published at the right time, they were left unanswered, first, because of the great inner political problems the country faced and, second, because of the outbreak of the First World War. In any case, Lánczy's plan, had it been realized, could not propose definitive solutions for the economic and social challenges Hungary had to face. The Budapest Universal Exhibition of 1917 might have indeed achieved at least some of those political, cultural and economic goals, which were described in the draft concepts of Blána, Zichy or Lánczy. The history of Hungarian proposals ends with the first coherent project of 1917.

\section{Conclusion}

In the period discussed here, hosting an international exhibition almost became a necessity for a modern country, a sign of political ambition, economic strength and cultural advancement. Capitals of leading colonialist countries (London, Paris), newly created nation states (Brussels), or conservative monarchies (Vienna) played the lead in this process. The role of capitals in increasing the international visibility of a country through the medium of exhibition is even more evident in the case of Italy: the fiftieth anniversary of the country's unification had been commemorated in 1911 by three exhibitions, organized simultaneously in the former and actual national capitals: Turin, Florence and Rome. The concepts for the Budapest Universal Exhibition reflected this new role of a modern national 
capital: through the organization of such an event Budapest would have appeared in the competition of nations as a new political, economic and cultural hub. Apart of being a capital of a semi-sovereign country, the fast growing Budapest would have been able to present many of the modern traits of a universal exhibition. ${ }^{45}$

The differences of the concepts for a Budapest universal exhibition throughout the period between the 1867 Austro-Hungarian Compromise and the dissolution of the historic state of Hungary in 1918 have indicated the transformation of a new modern political entity on the basis of its domestic and international circumstances. In the times of democracy and nationalism concepts for a Budapest universal exhibition are testimonies of its semi-sovereign statute. Hungary, perceived in 1867 as a newly created modern state by the international audience, had been ranked among other new nation states in way of modernization at the eastern and southern borders of the Monarchy. Due to its legal status within the Monarchy, the shared responsibilities with Austria, a continuous effort can be detected from the Hungarian administration to emphasize the nation's sovereign history, economy and culture in all communication towards the international audience.

The history of the ideas for a universal exhibition in Budapest reflects the changing approach to the image of Hungary and to the self-image of the Hungarians. On a more general level, the history of the plans for a Budapest universal exhibition also demonstrates the ambitions, the motivations and the expected results of a country in which nation building process and the accelerated modernization was manifested simultaneously within the frame of a newly created national administration. From the 1870s, this coincided, with the redefinition of 
the universal exhibition, when this typical phenomenon of the nineteenth century was no longer a collection of artefacts for a certain period of time, aimed at celebrating the common achievements of the Mankind. Exhibitions faced the seemingly contradictory challenge of professionalization of the exhibition industry, the thematic specialization, the needs for a mass entertainment, and the apparition of ephemeral pavilions as means of national representation. The plans for a Budapest universal exhibition indicate that Hungary, as any other country in the process of modernization, saw itself through the optics of its glorious past while the latest achievements of its political, economic and cultural modernization were demonstrated in the exhibition galleries and pavilions abroad as well as in the nation's capital. 


\section{Bibliography}

A londoni kiállítás ügyében működő Országos Központi Bizottmány 1862-dik april 26-ik napján tartott ülésének jegyzőkönyve. Pest: Herz János, 1862.

Alexander C. T. Geppert. Fleeting Cities: Imperial Expositions in Fin-de-Siècle Europe. New York: Palgrave Macmillan, 2009.

Ashby, Charlotte. 'The Pohjola Building: Reconciling Contradictions in Finnish Architecture around 1900', in Nationalism and Architecture, edited by Raymond Quek, Darren Deane and Sarah Butler, 135-145. Farnham: Ashgate, 2012.

Benedict Anderson. Imagined Communities: Reflections on the Origin and Spread of Nationalism. London, New York: Verso, 1983.

Bjarne Stoklund. 'How the Peasant House Became a National Symbol. A Chapter in the History of Museums and Nation-Building', Ethnologia Europaea, Journal of European Ethnology 29, no. 1 (1999): 5-18.

Blána, Szilárd. Egy terv Magyarországnak, illetve fóvárosának virágzóvá tételére, s ennek folytán a világkereskedelem és ipar közvetítő föpontjává leendő emelését. Budapest, 1874.

Cartledge, Bryan. The Will to Survive. A History of Hungary. New York: Columbia University Press, 2010.

Catalogue Special du Royaume de Hongrie. Paris, 1867.

Clegg, Elizabeth. Art, Design and Architecture in Central Europe, 1890-1920. Yale: Yale University Press, 2006.

Cornaglia, Paolo. 'A magyar pavilon az 1911-es torinói világkiállításon', in Pavilon építészet a 19-20. században a Magyar Építészeti Múzeum gyújteményéből, edited by Fehérvári Zoltán, Hajdú Virág, and Prakfalvi Endre, 79-96. Budapest: OMvH, Magyar Építézeti Múzeum, Pavilon Alapítvány, 2000.

Crowley, David. National Style and Nation-State: Design in Poland from the Vernacular Revival to the International Style. Manchester: Manchester University Press, 1992.

Csáki, Tamás. 'A finn építészet és az "architektúra magyar lelke." Kultúrpolitika, építészet, publicisztika a századelő Magyarországán', Múltunk 29, no. 1 (2006): 200-230.

De Gerandó neé Teleki, Emma. 1867diki világtárlat. Paris, 1868. 
Fejős, Zoltán. 'Nemzeti diskurzus és néprajz', in XIX. Nemzet és Müvészet. Kép és Önkép, edited by Király Erzsébet, Róka Enikő and Veszprémi Nóra, 83-111. Budapest, Magyar Nemzeti Galéria, 2010.

Filipová, Marta."'National Treasure or a Redundant Relic". The Roles of the Vernacular in Czech Art', RIHA Journal 0066. 26 February 2013.

Hobsbawn, Eric and Terence Ranger, ed. The Invention of Tradition. Cambridge: Cambridge University Press, 1983.

Hutvágner, Zsófia. ‘Az 1911-es drezdai Nemzetközi Higiéniai kiállítás Magyar pavilonja', in Székely Miklós (ed.) Opus Mixtum I - Proceedings of the Conference: Progressive Tendencies in Ephemeral Architecture (2012): 70-77.

Brockington, Grace, ed. Internationalism and the Arts in Britain and Europe. New York and Vienna: Peter Berg, 2009.

Jurecskó, László. 'K. Lippich Elek - a hivatalos művészetpolitika irányítója - és a Gödöllőiek,' Studia Comitatensia 10, no. 1 (1982): 10-28.

Keserü, Katalin. 'The Transformation of Architectural Thinking in Central Europe at the turn of the 20th Century' in Keserü, Katalin (ed.) The Beginnings of Modernism in Central European Architecture, 17-25. Budapest: Ernst Múzeum, 2005.

Lackner, Mónika. Az első magyar néprajzi gyüjtemény: a magyar népi kultúra prezentációja az 1873-as bécsi világkiállításon, in F. Dózsa, Katalin (ed.) Az áttörés kora. Bécs és Budapest a historizmus és az avantgárd között (1873-1920), Budapest, Budapesti Történeti Múzeum, 2004. 101-107.

Lánczy, Leó. Elöterjesztése Lánczy Leó förendiházi tagnak, a budapesti kereskedelmi és iparkamara elnökének a Budapesten 1917-ben rendezendő nemzetközi világkiállítás tárgyában. Budapest, 1911.

Lővei, Pál. 'Magyarország és a világkiállítások (főleg építészettörténeti vázlat)'. In Pavilonépítészet a 19-20. században a Magyar Építészeti Múzeum gyüjteményéből, edited by Zoltán Fehérváry, Virág Hajdú, Endre Prakfalvi, 17-64. Budapest: OMvH, Magyar Építézeti Múzeum, Pavilon Alapítvány, 2000.

Magdó, Eszter. 'Magyar részvétel az 1906-os Román Általános Kiállításon'. In Opus Mixtum I - Proceedings of the Conference: Progressive Tendencies in Ephemeral Architecture, edited by Miklós Székely (2012): 36-47.

Mitchell, Timothy. 'The World as Exhibition', Comparative Studies in Society and History 31, no. 2 (1989): 222-230. 
Moravánszky, Ákos. Competing Visions: Aesthetic Invention and Social Imagination in Central European Architecture, 1867-1918. Cambridge, Massachusetts, London, 1998.

Pócs, Dániel. A Didymus corvina. Hatalmi reprezentáció Mátyás király udvarában. Budapest: Institute of Art History, Research Centre of the Humanities, Hungarian Academy of Sciences, 2012.

Rampley, Matthew. 'Peasants in Vienna. Ethnographic Display and the 1873 World's Fair', Austrian History Yearbook 42 (2011): 110-132.

Sármány-Parsons, Ilona. 'Ungarns Millenniumsjahr 1896'. In Der Kampf um das Gedächtnis. Öffentliche Gedenktage in Mitteleuropa, edited by Emil Brix and Hannes Stekl, 273-291. Vienna: Boehlau, 1997.

Sinkó, Katalin, 'A millenniumi kiállítás mint Gesamkunstwerk', in A historizmus müvészete Magyarországon, edited by Anna Zádor, 132-147. Budapest: Institute of Art History, Hungarian Academy of Sciences, 1993.

Sinkó, Katalin. 'Az Alföld és az alföldi pásztorok felfedezése a külföldi és a hazai képzőművészetben', Ethnogaphia 100 (1989): 121-154.

Sisa, József. 'The Beginnings of Art History and Museology in Hungary. Some Semper Connections', Centropa 2, no. 2 (2002): 128-135.

Stirton, Paul. 'From "The Stones of Venice" to "The Stones of Transylvania": Károly Kós, Ruskin and the English Arts and Crafts Tradition'. In Britain and Hungary: Contacts in Architecture, Design, Art and Theory 3, edited by Gyula Ernyey, 166179. Budapest: Hungarian University of Craft and Design, 2005.

Török, Gyula. A Turini világkiállítás magyar háza. Budapest, 1912.

Unowsky, Daniel. 'Staging Habsburg Patriotism: Dynastic Loyalty and the 1898 Imperial Jubilee'. In Constructing Nationalities in East Central Europe, edited by Pieter Judson and Marsha Rozenblit, 141-156. Berghahn Books, 2004.

Unowsky, Daniel. The Pomp and Politics of Patriotism: Imperial Celebrations in Habsburg Austria, 1848-1916. West Lafayette: Purdue, 2005.

Vadas, Ferenc. 'Programtervezetek a Millennium megünneplésére (1893)', Ars Hungarica 24, no. 1 (1996): 3-55.

Wesemael, Pieter van. Architecture of Instruction and Delight. A Socio-historical analysis of World Exhibitions as a didactic phenomenon (1798-1851-1970). Rotterdam: 010, 2001. 
${ }^{1}$ Bryan Cartledge, The Will to Survive. A History of Hungary (New York, 2010), pp. 219-250.

2 Daniel Unowsky, 'Staging Habsburg Patriotism: Dynastic Loyalty and the 1898 Imperial Jubilee', in Constructing Nationalities in East Central Europe, ed. Pieter Judson and Marsha Rozenblit (New York, Oxford, 2004); Daniel Unowsky, The Pomp and Politics of Patriotism: Imperial Celebrations in Habsburg Austria, 18481916 (West Lafayette, 2005).

${ }^{3}$ A londoni kiállitás ügyében müködő Országos Központi Bizottmány 1862-dik april 26ik napján tartott ülésének jegyzökönyve (Pest, 1862), 12.

${ }^{4}$ Catalogue Special du Royaume de Hongrie (Paris, 1867).

${ }^{5}$ De Gerandóné Teleki, Emma, 1867diki világtárlat (Paris, 1868), 518-519.

6 Árpád Mikó, 'A reneszánsz művészet története Magyarországon', (a doctoral thesis, Hungarian Academy of Sciences, Budapest 2011). Dániel Pócs, A Didymus corvina. Hatalmi reprezentáció Mátyás király udvarában (Budapest, 2012),

${ }^{7}$ Pieter van Wesemael, Architecture of Instruction and Delight. A Socio-historical analysis of World Exhibitions as a didactic phenomenon (1798-1851-1970) (Rotterdam, 2001), 136-142.

${ }^{8}$ Mónika Lackner, 'Az első magyar néprajzi gyüjtemény: a magyar népi kultúra prezentációja az 1873-as bécsi világkiállításon’, in Az áttörés kora. Bécs és Budapest a historizmus és az avantgárd között (1873-1920), ed. Katalin F. Dózsa (Budapest, 2004), 101-110.

${ }^{9}$ Sinkó, Katalin, ‘Az Alföld és az alföldi pásztorok felfedezése a külföldi és a hazai képzőmüvészetben', Ethnogaphia 100 (1989): 121-154; Lackner, 'Az első magyar’, 101-110. 
${ }^{10}$ Sinkó, Az Alföld, 121-131.

${ }^{11}$ Bjarne Stoklund, 'How the Peasant House Became a National Symbol. A Chapter in the History of Museums and Nation-Building', Ethnologia Europaea, Journal of European Ethnology 29, no.1 (1999): 5-18.

${ }^{12}$ Matthew Rampley, 'Peasants in Vienna. Ethnographic Display and the 1873 World’s Fair', Austrian History Yearbook 42 (2011): 110-32.

${ }^{13}$ Szilárd Blána, Egy terv Magyarországnak, illetve fóvárosának virágzóvá tételére, s ennek folytán a világkereskedelem és ipar közvetitö fópontjává leendö emelését (Budapest, 1874).

14 Alexander C. T. Geppert, Fleeting Cities: Imperial Expositions in Fin-de-Siècle Europe (New York, 2009).

${ }^{15}$ Blána, Egy terv Magyarországnak, 17-18.

${ }^{16}$ Timothy Mitchell, ‘The World as Exhibition', Comparative Studies in Society and History 31, no. 2 (1989): 222-230.

${ }^{17}$ Pál Lővei, 'Magyarország és a világkiállítások (föleg építészettörténeti vázlat)', in Pavilonépítészet a 19-20. században a Magyar Épitészeti Múzeum gyüjteményéből, ed.

Zoltán Fehérváry, Virág Hajdú and Endre Prakfalvi (Budapest, 2000), 21.

${ }^{18}$ Blána, Egy terv Magyarországnak, 1.

${ }^{19}$ Mitchell, 'The World as Exhibition', 222-224.

${ }^{20}$ Ferenc Vadas, ‘Programtervezetek a Millennium megünneplésére (1893)’, Ars

Hungarica 24, no. 1 (1996): 44-46.

${ }^{21}$ Vadas, 'Programtervezetek’, 4-11.

${ }^{22}$ Vadas, 'Programtervezetek', 6-8, 12. 
${ }^{23}$ Even though Zichy used the Hungarian word világkiállítás (world exhibition) in his draft, he referred to the event as országos kiállítás (a general national exhibition) in other printed versions which drew on the legacy of the 1885 event. It is highly probable that in Zichy's approach the universality of the exhibition would have been ensured by a high number of foreign (international) visitor for whom the new Hungarian economy and cultural life would have been presented.

${ }^{24}$ Katalin Sinkó, ‘A millenniumi kiállítás mint Gesamkunstwerk’, in A historizmus müvészete Magyarországon, ed. Anna Zádor (Budapest, 1993), 141.

${ }^{25}$ József Sisa, 'The Beginnings of Art History and Museology in Hungary. Some Semper Connections’, Centropa 2, no. 2 (2002): 128-135.

${ }^{26}$ Katalin Keserü, 'The Transformation of Architectural Thinking in Central Europe at the turn of the 20th Century', in The Beginnings of Modernism in Central European Architecture, ed. Katalin Keserü (Budapest, 2005), 17-24. Ákos Moravánszky, Competing Visions: Aesthetic Invention and Social Imagination in Central European Architecture, 1867-1918 (Cambridge, Massachusetts, London, 1998), 217-284.

${ }^{27}$ Eric Hobsbawn, The Invention of Tradition (Cambridge, 1983), 263-307, Benedict Anderson, Immagined Communities (London, New York 1983), 83-112.

${ }^{28}$ Rebecca Houze 'National Internationalism. Reactions to Austrian and Hungarian Decorative Arts at the 1900 Paris Exposition Universelle', Studies in the Decorative Arts 12, (2004-2005): 55-97.

${ }^{29}$ Zoltán Fejős, 'Nemzeti diskurzus és néprajz', in XIX. Nemzet és Müvészet. Kép és Önkép, ed. Erzsébet Király, Enikő Róka and Nóra Veszprémi (Budapest, 2010), 110_ 111. 
${ }^{30}$ Cf. for example Grace Brockington, ed., Internationalism and the Arts in Britain and Europe (Oxford, 2009); Elizabeth Clegg, Art, Design and Architecture in Central Europe, 1890-1920 (New Haven, 2006); David Crowley, National Style and NationState: Design in Poland from the Vernacular Revival to the International Style (Manchester, 1992); Marta Filipová, ‘’National Treasure or a Redundant Relic”. The Roles of the Vernacular in Czech Art', RIHA Journal 0066, Accessed 4 June 2013, http://www.riha-journal.org/articles/2013/2013-jan-mar/filipova-national-treasure-or-aredundant-relic; Charlotte Ashby, 'National Style versus Modernity: Reconciling Contradictions in Finnish Architecture around 1900', in Nationalism and Architecture, ed. Raymond Quek, Darren Deane and Sarah Butler (Farnham, 2012).

${ }^{31}$ Tamás Csáki, ‘A finn építészet és az “architektúra magyar lelke.” Kultúrpolitika, építészet, publicisztika a századelő Magyarországán’, Múltunk 29, no .1 (2006): 200_ 230.

${ }^{32}$ Paul Stirton, 'From “The Stones of Venice” to "The Stones of Transylvania”: Károly Kós, Ruskin and the English Arts and Crafts Tradition', in Britain and Hungary: Contacts in Architecture,

Design, Art and Theory, Vol. 3, Gyula Ernyey (ed.), Hungarian University of Craft and Design, Budapest, 2005, 166-179.

${ }^{33}$ Hungarian pavilions in Milan and Bucharest (both in 1906); Turin and Dresden (both in 1911) echoed this new concept. Cf. Eszter Magdó, 'Magyar részvétel az 1906-os Román Általános Kiállításon,' in Opus Mixtum 1/1 - Proceedings of the Conference: Progressive Tendencies in Ephemeral Architecture, ed. Miklós Székely (2012): 36-47; 
Zsófia Hutvágner, ‘Az 1911-es drezdai Nemzetközi Higiéniai kiállítás Magyar pavilonja', in Opus Mixtum 1, no. 1, 70-77.

${ }^{34}$ Gyula Török, A Turini világkiállítás magyar háza (Budapest, 1912), 4-8.

${ }^{35}$ Paolo Cornaglia, ‘A magyar pavilon az 1911-es torinói világkiállításon’, in Pavilon építészet a 19-20. században a Magyar Épitészeti Múzeum gyüjteményéböl, ed. Zoltán Fehérvári, Virág Hajdú and Endre Prakfalvi (Budapest, 2000), 79-88.

${ }^{36}$ László Jurecskó, ‘K. Lippich Elek - a hivatalos müvészetpolitika irányítója - és a Gödöllőiek', Studia Comitatensia 10, no. 1 (1982): 10-28.

${ }^{37}$ Leó Lánczy, Elöterjesztése Lánczy Leó förendiházi tagnak, a budapesti kereskedelmi és iparkamara elnökének a Budapesten 1917-ben rendezendö nemzetközi világkiállítás tárgyában (Budapest, 1911), 1.

${ }^{38}$ Lánczy, Elöterjesztése Lánczy Leó, 5.

${ }^{39}$ Lánczy, Előterjesztése Lánczy Leó, 5.

${ }^{40}$ Lánczy, Előterjesztése Lánczy Leó, 2.

${ }^{41}$ Lánczy, Elöterjesztése Lánczy Leó, 10.

${ }^{42}$ Lánczy, Elöterjesztése Lánczy Leó, 10.

${ }^{43}$ Lánczy, Elöterjesztése Lánczy Leó, 10.

${ }^{44}$ Lánczy, Elöterjesztése Lánczy Leó, 10.

${ }^{45}$ Three new bridges over the Danube, new railway stations, the first electronic underground line, new university buildings, theatres, museums and many other investments were made for the Millennium festivities in 1896. Ilona Sármány-Parsons, 'Ungarns Millenniumsjahr 1896', in Der Kampf um das Gedächtnis. Öffentliche Gedenktage in Mitteleuropa, ed. Emil Brix and Hannes Stekl (Vienna, 1997), 273-291. 